\title{
Refractive results of cataract surgery using optical biometry and Haigis formula in eyes with refractive keratotomy
}

\author{
Resultado refracional da cirurgia de catarata utilizando biômetro \\ óptico e fórmula Haigis em olhos com ceratotomia refrativa
}

Juan Carlos Sánchez Caballero'; Virgilio Centurion²

\begin{abstract}
Objective: To analyze refractive results in postoperative cataract surgery in eyes previously submitted to keratotomy using Haigis formula and data provided by IOL Master ${ }^{\circledR}$ optical biometer. Methods: The measurements for IOL calculation were obtained through optical biometry by partial coherence interferometry (IOL Master ${ }^{\circledR}$ - Zeiss, 5.4 and 5.5 version) that provides us with the axial length, the central keratometry of $2.5 \mathrm{~mm}$, white-to-white diameter and anterior chamber anatomical depth. The formula chosen was Haigis. The surgical technique applied was with the scleral incision at $1.5 \mathrm{~mm}$ from the limbus, with scleral-corneal tunnel of $2.2 \mathrm{~mm}$ wide, phacoemulsification using INFINITI Ozil $l^{\circledR}$ - Alcon and implantation of hydrophobic acrylic aspheric intraocular lens - SN60WF ${ }^{\circledR}$ Alcon. Results: We studied 20 eyes submitted to keratotomy in the past and currently with cataract with indication for cataract surgerywith intraocular lens implantation using phacoemulsification. Postoperative spherical equivalent was plano in $40 \%$ of the eyes and lower than -1.00 in $85 \%$ of the eyes. Conclusion: The optical biometry by partial coherence interferometry associated with Haigis formula is a valid alternative in IOL calculation for eyes submitted to keratotomy. The refractive results are highly predictable and reproducible.

Keywords: Intraocular lens;Anterior chamber; keratotomy, radial; Biometry/instrumentation; Axial length, eye/pathology
\end{abstract}

\section{ReSUMO}

Objetivo: Analisar os resultados refracionais no pós-operatório de cirurgia de catarata em olhos previamente submetidos à ceratotomia, utilizando a fórmula Haigis e os dados fornecidos pelo biômetro óptico IOL Master ${ }^{\circledR}$. Métodos: As medidas para o cálculo da LIO foram obtidas por meio da biometria óptica por interferometria de coerência parcial (IOL Master ${ }^{\circledR}$ - Zeiss, versão 5.4 e 5.5) que nos fornece o comprimento axial, a ceratometria central de $2.5 \mathrm{~mm}$, o diâmetro branco-a-branco e a profundidade anatômica da câmara anterior. A fórmula escolhida foi a Haigis. A técnica cirúrgica aplicada foi com incisão escleral a $1.5 \mathrm{~mm}$ do limbo, com túnel esclerocorneal de $2.2 \mathrm{~mm}$ de largura, facoemulsificação com equipamento INFINITI Ozil ${ }^{\circledR}$ - Alcon e implante de lente intraocular acrílica hidrofóbica asférica - SN60WF ${ }^{\circledR}$ - Alcon. Resultados: Foram estudados 20 olhos submetidos à ceratotomia no passado e atualmente portadores de catarata com indicação de facectomia com implante de lente intraocular por meio da facoemulsificação. O equivalente esférico pós-operatório foi plano em $40 \%$ dos olhos e menor que $-1.00 \mathrm{em} 85 \%$ dos olhos. Conclusão: A biometria óptica por interferometria de coerência parcial associada à fórmula Haigis se apresenta como uma alternativa válida no cálculo da LIO em olhos submetidos à ceratotomia. Os resultados refrativos são altamente previsíveis e reproduzíveis.

Descritores: Lentes intraoculares; Câmara anterior; Ceratotomia radial; Biometria/instrumentação; Comprimento axial do olho

'Oftalmologista do Instituto de Moléstias Oculares (IMO) - São Paulo (SP), Brasil; ${ }^{2}$ Oftalmologista do Instituto de Moléstias Oculares (IMO) - São Paulo (SP), Brasil.

Trabalho realizado no Instituto de Moléstias Oculares (IMO) - São Paulo (SP), Brasil

The authors declare no conflicts of interest

Recebido para publicação em: 28/6/2012 - Aceito para publicação em: 27/1/2012

Rev Bras Oftalmol. 2013; 72 (2): 103-7 


\section{INTRODUCTION}

$\mathbf{I}$ ndividuals submitted to keratotomy for correction of myopia and / or astigmatism in the 80 's, an average age of 30 , now reaching 60 years, are looking for cataract surgery or for surgical correction of other refractive errors such as secondary progressive hyperopia.These patients have behavioral characteristics that is known as "refractive profile", that is, they are individuals who have had correction of refractive errors and now, at the moment of selecting a new surgery they have an expectation equal to or higher than in the first experience. They are well informed about advances in eye surgery and demand or expect to have results that meet or exceed their expectations ${ }^{(1)}$.

Another characteristic is related to the cornea that usually shows a progressive central flattening, with fluctuation of the visual acuity. When submitted to lens surgery may have a significant flattening, though temporary, which may compromise the final result $t^{(2)}$.

Refractive $^{(1)}$ predictability and reproducibility of IOL calculation may be difficult due to the peculiarities of the cornea previously submitted to keratotomy.

The objective of this study is to analyze the cataract surgery postoperative refractive results in eyes previously submitted to keratotomy, using Haigis formula and the data provided by IOL Master $^{\circledast}$ optical biometer.

\section{Methods}

This is a retrospective, non-comparative study of 20 eyes which were submitted to keratotomy in the past and have cataract with an indication for intraocular lens implantation by phacoemulsification.

All the eyes underwent a complete ophthalmologic examination with emphasis on the biomicroscopy of the anterior segment, for analysis of radial cuts in the cornea, IOL calculation, analysis of vision potential (PAM) and evaluation of retina.

The measurements for IOL calculation were obtained from the optical biometry based on partial coherence interferometry (IOL Master ${ }^{\circledR}$, Zeiss, version 5.4, 5.5). This equipment provides:

1. Axial length

2. Central keratometry of $2.50 \mathrm{~mm}$

3. White-to-white diameter

4. Anatomic depth of the anterior chamber.

To obtain more detailed analysis of the corneal surface,the eyes were submitted to corneal topography (Tomey - TMS) and corneal tomography (Pentacam - Oculus).

The keratometry used for the calculation of IOL was the one provided by IOL Master ${ }^{\circledR}$ that when compared to Pentacam ${ }^{\circledR}$, module Holladay Report, the $3 \mathrm{~mm}$ does not present a significant difference.

The biometric formula used was Haigis. The surgical technique was with scleral incision $1.50 \mathrm{~mm}$ from the limbus, with sclero-corneal tunnel of $2.2 \mathrm{~mm}$ wide, phacoemulsification using Alcon INFINITI equipment and implantation of hydrophobic acrylic aspheric intraocular lens - SN60WF - Alcon. All surgeries were performed by one surgeon (VC). The refraction studied was collected between the third and the sixth months postoperative. The chosen preoperative target refraction in biometric calculation was for emmetropia (plano).

All patients signed an inform consent about the procedure.

The statistic method used was the T Student.

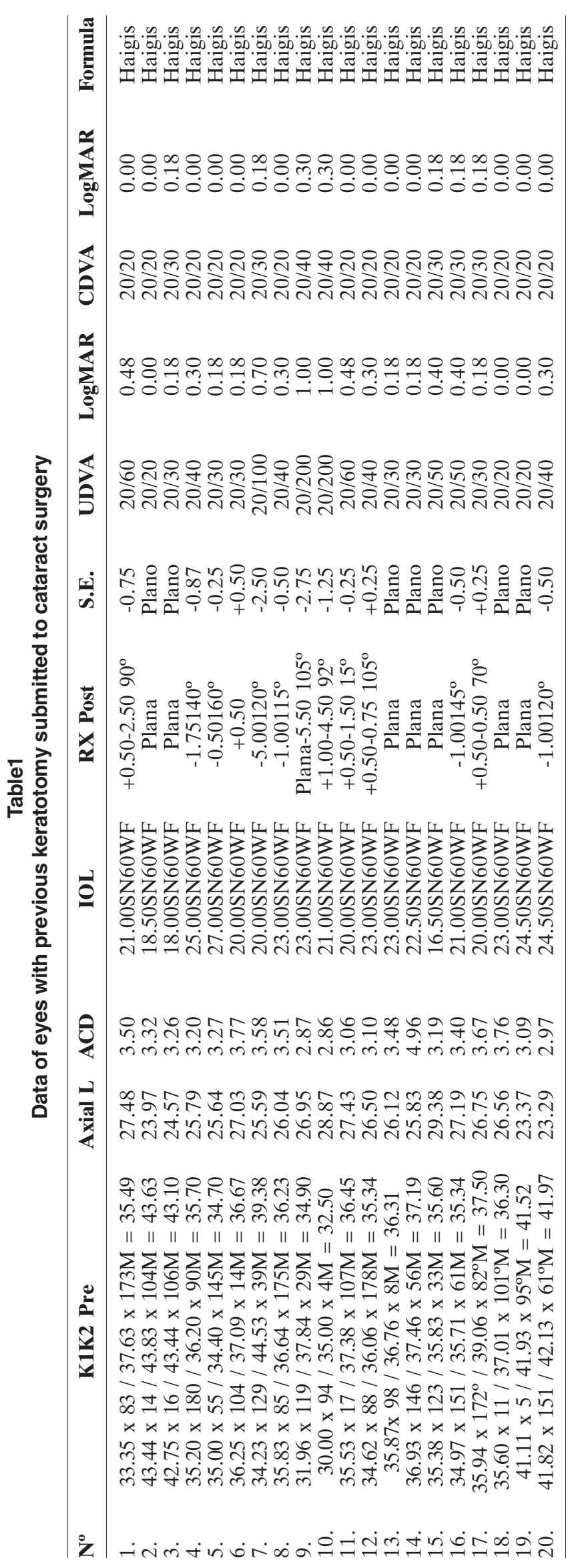


Table 2

Average preoperative keratometry

\begin{tabular}{lcc}
\hline 32.50 to 34.00 & 1 & $5 \%$ \\
34.25 to 36.00 & 7 & $35 \%$ \\
36.25 to 38.00 & 7 & $35 \%$ \\
38.25 to 40.00 & 1 & $5 \%$ \\
40.25 to 42.00 & 2 & $10 \%$ \\
42.25 to 44.00 & 2 & $10 \%$ \\
\hline Total & 20 & $100 \%$ \\
\hline
\end{tabular}

Table 4

Preoperative refraction and preoperative spheric equivalent, postoperative refraction and postoperative spheric equivalent

\begin{tabular}{lcccc}
\hline $\mathbf{N}^{\mathbf{0}}$ & RX Pre & S.E. Pre & RX Post & S.E. Post \\
\hline 1. & $-0.50-1.7570^{\circ}$ & -1.37 & $+0.50-2.5090^{\circ}$ & -0.75 \\
2. & +1.50 & +1.50 & Plano & Plano \\
3. & +1.50 & +1.50 & Plano & Plano \\
4. & $+2.75-0.5030$ & +2.50 & $-1.75140^{\circ}$ & -0.87 \\
5. & $+4.00-1.00180$ & +3.50 & $-0.50160^{\circ}$ & -0.25 \\
6. & +0.50 & +0.50 & +0.50 & +0.50 \\
7. & $+2.00-5.00135^{\circ}$ & -0.50 & $-5.00120^{\circ}$ & -2.50 \\
8. & $+1.50-1.0085^{\circ}$ & +1.00 & $-1.00115^{\circ}$ & -0.50 \\
9. & $-1.00145^{\circ}$ & -0.50 & Plano $-5.50105^{\circ}$ & -2.75 \\
10. & $-1.00-4.0090^{\circ}$ & -3.00 & $+1.00-4.5092^{\circ}$ & -1.25 \\
11. & $-4.00-2.0035^{\circ}$ & -5.00 & $+0.50-1.5015^{\circ}$ & -0.25 \\
12. & $-1.0080^{\circ}$ & -0.50 & $+0.50-0.75105^{\circ}$ & +0.25 \\
13. & $+1.00-0.5090^{\circ}$ & +0.75 & Plano & Plano \\
14. & +2.00 & +2.00 & Plano & Plano \\
15. & $-4.75-0.75180^{\circ}$ & -5.12 & Plano & Plano \\
16. & $-2.00-0.5045^{\circ}$ & -2.25 & $-1.00145^{\circ}$ & -0.50 \\
17. & $-0.5070^{\circ}$ & -0.25 & $+0.50-0.5070^{\circ}$ & +0.25 \\
18. & $+1.50-0.2550^{\circ}$ & +1.38 & Plano & Plano \\
19. & +3.50 & +3.50 & Plano & Plano \\
20. & $+3.00-1.00110^{\circ}$ & +2.50 & $-1.00120^{\circ}$ & -0.50 \\
\hline
\end{tabular}

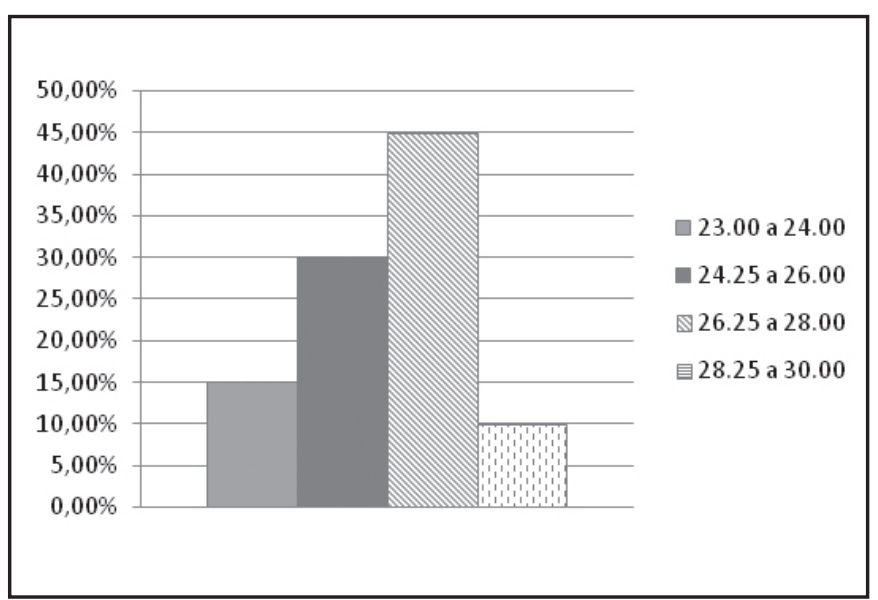

Figure 1: Axial length
Table 3

Postoperative refraction (spheric equivalent)

\begin{tabular}{lcc}
\hline Plano & 8 & $40 \%$ \\
+0.50 a -0.50 & 7 & $35 \%$ \\
-0.75 a -1.00 & 2 & $10 \%$ \\
$>-1.00$ & 3 & $15 \%$ \\
\hline Total & 20 & $100 \%$ \\
\hline
\end{tabular}

Table 5

Postoperative UDVA

\begin{tabular}{lcr}
\hline $20 / 20$ & 3 & $15 \%$ \\
$20 / 30$ & 6 & $30 \%$ \\
$20 / 40$ & 4 & $20 \%$ \\
$20 / 50$ & 2 & $10 \%$ \\
$20 / 60$ & 2 & $10 \%$ \\
$20 / 100$ & 1 & $5 \%$ \\
$20 / 200$ & 2 & $10 \%$ \\
\hline Total & 20 & $100 \%$ \\
\hline
\end{tabular}

Table 6

Postoperative CDVA

\begin{tabular}{lcc}
\hline $20 / 20$ & 13 & $65 \%$ \\
$20 / 30$ & 5 & $25 \%$ \\
$20 / 40$ & 2 & $10 \%$ \\
\hline Total & 20 & $100 \%$ \\
\hline
\end{tabular}

\section{Results}

Table 1 shows the relationship of the eyes studied with the following data: preoperative keratometry, axial length, anterior chamber depth (ACD), implanted IOL, postoperative refraction, spherical equivalent (SE), postoperative visual acuity with and without correction and formula used.

Preoperative keratometry varied from $32.50 \mathrm{D}$ to $43.63 \mathrm{D}$ (Table 2).

Axial length varied from $23.00 \mathrm{~mm}$ to $29.38 \mathrm{~mm}$ (Figure 1).

Average spheric equivalent in postoperative refraction was plano in $40 \%$ of the eyes and lower than -1.00 in $85 \%$ of the eyes (Table 3 ).

\section{Statistical analysis}

Applying the $\mathrm{T}$ test in relation to a previously planned refraction, if it is plano $=0$, one obtains statistical $t=2.3941$ with $\mathrm{p}=0.02714$ which means that the mean random variable of postsurgical spheric equivalent is statistically different from zero.

The uncorrected distance visual acuity is shown in table 5 .

Postoperative CDVA is shown in table 6. 


\section{Discussion}

The calculation of IOL power depends on the method used, data on axial length, data on corneal power and biometric formula $^{(3)}$.

The method used in this study was optical biometry with the IOL Master - Zeiss ${ }^{\circledR}(5.4$ - 5.5) which makes the calculation of axial length by partial coherence interferometry and has proved more efficient than contact ultrasonic biometry ${ }^{(4)}$.

Corneal power, the focus of major controversy in the eyes with keratotomy ${ }^{(2)} \mathrm{scar}$, is obtained by the autorefractor biometer in a central area of $2.50 \mathrm{~mm}$ (different from manual keratometry that provides values of an area of $\left.4.00 \mathrm{~mm}^{(5)}\right)$.

In addition to our routine corneal power provided by the biometer, we obtained an extra keratometry with topographer (Pentacam - Oculus) that in the module Holladay Report allows us to choose the keratometric value in a central area of $3.0 \mathrm{~mm}^{(6)}$. In the latest versions of the IOL Master ${ }^{\circledR}$ Zeiss (5.4 and 5.5), this double control is not necessary, because the results are extremely consistent.

We completed the propaedeutics of anterior corneal surface with topography (Tomey, TMS) that facilitates the interpretation of the irregularities of corneal surface, in particular, by the presence of irregular astigmatism ${ }^{(7)}$.

We must remember that the keratotomy alters the curvature of the anterior and posterior central cornea, keeps the parallelism of the two faces, therefore, it does not alter the refractive index of the cornea ${ }^{(8)}$.

In relation to biometric formula, our choice is Haigis, which using the data provided by thebiometer has shown an excellent refractive predictability ${ }^{(3,6,8)}$. This predictability is attributed to the fact that Haigis formula "does not depend on" the corneal power directly, but on the anatomic depth of the anterior chamber and its relationship to axial length. According to Aramberri, it is the only formula that excludes the Double-Kmethod ${ }^{(9)}$. IOL constants should be updated monthly on specific sites, thus optimizing IOL diopter, IOL model and the appropriate formula.

Our results prove the efficacy of Haigis formula in eyes post keratotomy.

We have no doubts in stating that the measurement of axial length by optical method is the best option, not only in routine cases as well in challenging cases.

Among the last generation formulas, we highlight Haigis that has been very predictable and reproducible in terms of refraction.

However, IOL calculation in eyes previously submitted to keratotomy, is a challenge to obtain a precise and real keratometry of the smaller central area of the cornea, which is supposed to be the location through which passes the visual and anatomic axis of the eye.

A simplified explanation of what happens to the cornea after keratotomy, is the transformation of the physiological prolate corneal dome (central portion more curved than periphery) on an oblate surface (flattening of the central portion maintaining pheripheral curve $)^{(1)}$.

Specifically in eyes after keratotomy, central corneal flattening happens both in its anterior and the posterior faces, not changing the refractive index $(\mathrm{n}=1.3375)$.

The total power of the cornea has been calculated since the nineteenth century by using a value $\mathrm{n}=1.3375$, called standard keratometricindex, which compensates for the negative power of the posterior face of the cornea, which placido keratometer sand topographers cannot calculate.
This $\mathrm{K}$ value calculated with $\mathrm{n}=1.3375$ provides a power greater than the real one in eyes submitted to lasik, PRK, keratotomy, etc. Haigis proved that with 1.3375 what is actually calculated is the back vertex power, while with 1.3315 it is obtained the equivalent power of the cornea ${ }^{(10)}$.

This characteristic definitely changes the ELP calculation (effective lensposition) when compared with corneas which have not undergone corneal refractive procedures.

It is important to note that the Haigis formula uses anterior chamber axial length and anatomic depth, not depending on corneal height.

By using three constants $(\mathrm{a} 0=$ related to nominal constant provided by the manufacturer, a1 = anterior chamber measure and $\mathrm{a} 2$ = axial length measure) instead of one, like the other formulas, Haigis has the ability to estimate the actual position of the lens in the anterior segment. There is no need for correction factor or to use double-K method, as it is not dependent on the corneal power to calculate the $\mathrm{IOL}^{(1)}$.

The surgical technique, with scleraldelamination at $1.5 \mathrm{~mm}$ from the limbus, with sclero-corneal tunnel of $2.2 \mathrm{~m}$ wide, contributed to not modify the already changed corneal surface and with this technique we have not had secondary hyperopia that can last up to \pm 8 weeks postoperative ${ }^{(11)}$, not even being necessary to suture radial incisions that occur during surgical manipulation.

We must be aware that corneas submitted to keratotomy suffer central flattening, going from prolate to oblate, and that this flattening can be progressive, therefore, interfering with the postoperative refraction target ${ }^{(12)}$.

Many of these corneaspresent refractive diuturnal fluctuations, beingflatter in the morning and with the greater curvature in the afternoon ${ }^{(9)}$.

Another interesting fact is the appearance in the immediate postoperative period of a hyperopic refraction (up to +3.50 D), perhaps due to corneal edema at the site of radial incisions, which leads to a flattening of the central cornea. Not to perform any surgical intervention like IOL exchange, because in most cases there is an involution of this hyperopia and it is not rare for the eye to get close to an emmetropia. Wait about 8 weeks ${ }^{(11,13,14)}$

During the preoperative examination, take into consideration the number of incisions, because the higher the number the greater the possibility of refractionalinstability ${ }^{(15)}$. It is also important the optical zone size; and the smaller, the greater the difficulty in calculating cornealpower ${ }^{(15)}$.

There are reports on the influence of height above sea level, which may influence the final result and visual fluctuation $^{(16)}$

Regarding the choice of IOL there are no standards or consensus in the literature ${ }^{(4,12,15)}$. Better an aspheric IOL to reduce spherical aberrations induced by keratotomy.Better monofocal.The toric IOL may be indicated if the astigmatism was stable, central and symmetrical. We must consider that astigmatism may change over time. Multifocal IOLs, refractive or diffractive, have formal counter-indication, because we believe that the undesirable optical lens phenomena added to the keratotomy scars may compromise the quality of vision.

Theoretically, some models of single piece accommodative IOL may perhaps be implanted without visual impairment.

In conclusion, optical biometry by partial coherence interferometry associated with the Haigis formula is presented as a valid alternative in the calculation of IOL in eyes submitted to keratotomy. The refractive results are highly predictable and reproducible. 


\section{ReFERENCES}

1. Caballero JC, Centurion V. O essencial em biometria: uma resposta apropriada para cada caso. Rio de Janeiro: Cultura Médica;2012.p.65-9.

2. Koppen C, Gobin L, Tassignon MJ. Intacs to stabilize diurnal variation in refraction after radial keratotomy. J Cataract Refract Surg. 2007;33(12):2138-41.

3. Zacharias W. As formulas biométricas. In: Centurion V. Excelência em biometria. Rio de Janeiro: Cultura Médica;2006. p.95-102.

4. Stakheev AA. Intraocular lens calculation for cataract after previous radial keratotomy. Ophthalmic Physiol Opt. 2002;22(4):289-95.

5. Muraine M, Siahmed K, RetoutA, Brasseur G. [Phacoemulsification following radial keratotomy. Topographic and refractive analysis concerning an 18-month period (apropos of a case)]. J FrOphtalmol. 2000;23(3):265-9. French.

6. Holladay JT, Hill WE, Steinmueller A. Corneal power measurements using scheimpflug imaging in eyes with prior corneal refractive surgery. J Refract Surg. 2009;25(10):862-8. Erratum in J Refract Surg. 2010;26(6):387. Comment in J Refract Surg. 2010;26(6):388-9; author reply 389-91.

7. Bardocci A, Lofoco G. Corneal topography and postoperative refraction after cataract phacoemulsification following radial keratotomy. Ophthalmic Surg Lasers. 1999;30(2):155-9.

8. Kim SW,Kim EK, Cho BJ,Kim SW, Song KY,Kim T. Use of the pentacam true net corneal power for intraocular lens calculation in eyes after refractive corneal surgery. J Refract Surg. 2009;25(3):285-9.

9. Aramberri J. Special circumstances: double-K method. In: Hoffer KJ. IOL power. Thorofare: Slack; 2011.p.199-206.
10. Haigis W. Cornealpowerafterrefractivesurgery for myopia: contactlensmethod. J CataractRefract Surg. 2003;29(7):1397-411.Erratum inJ Cataract Refract Surg. 2003;29(10):1854.

11. Haigis W.The Haigis formula. In: Shammas HJ. Intraocular lens power calculations. Thorofare: Slack;2004. p.41-57.

12. Han ES, Lee JH. Intraocular lens power calculation in high myopic eyes with previous radial keratotomy. J Refract Surg. 2006;22(7):713-6.

13. Centurion V, Caballero JCS. Hyperopic shift after phacoemulsification in eyes with previous radial keratotomy [video]. World Ophthalmology Congress; 2006 fev. 19-24, São Paulo, Brasil. (First Prize Cataract Category).

14. Centurion V, Caballero JC. Hyperopic shift after phacoemulsification in eyes with previous radial keratotomy [Video]. J CataractRefract Surg. 2005;21(3).

15. Awwad ST, Dwarakanathan S, Bowman RW, Cavanagh HD, Verity SM, Mootha VV,et al. Intraocular lens power calculation after radial keratotomy: estimating the refractive corneal power. J Cataract Refract Surg. 2007;33(6):1045-50.

16. Lyle WA, Jin GJ. Intraocular lens power prediction in patients who undergo cataract surgery following previous radial keratotomy. ArchOphthalmol. 1997;115(4):457-61.Comment in Arch Ophthalmol. 1997;115(4):542-3.

\section{Autor correspondente:}

Juan Carlos Sánchez Caballero

Av. Ibirapuera, ${ }^{\circ} 624$ - Ibirapuera

CEP 04028-000 - São Paulo (SP), Brasil

E-mail: juancaballero@imo.com.br 